U.S.Geological Survey Terrestrian,Freshwater and Marine Ecosystem Program

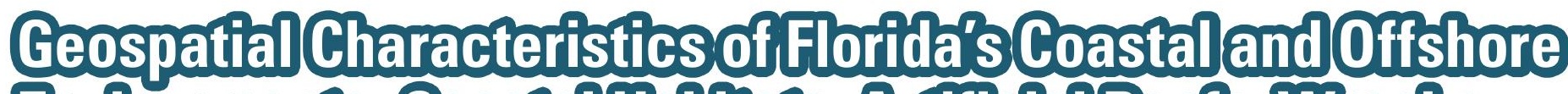

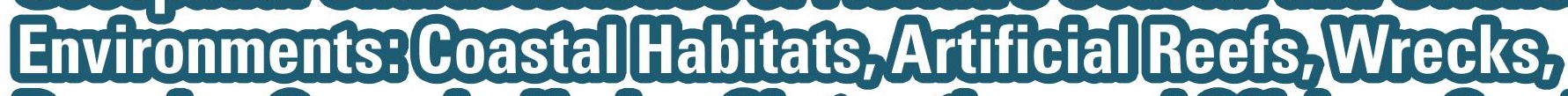
Dumphing Gromds, Harbor Obstructionsend Offshoro Sand

\title{
Besources
}

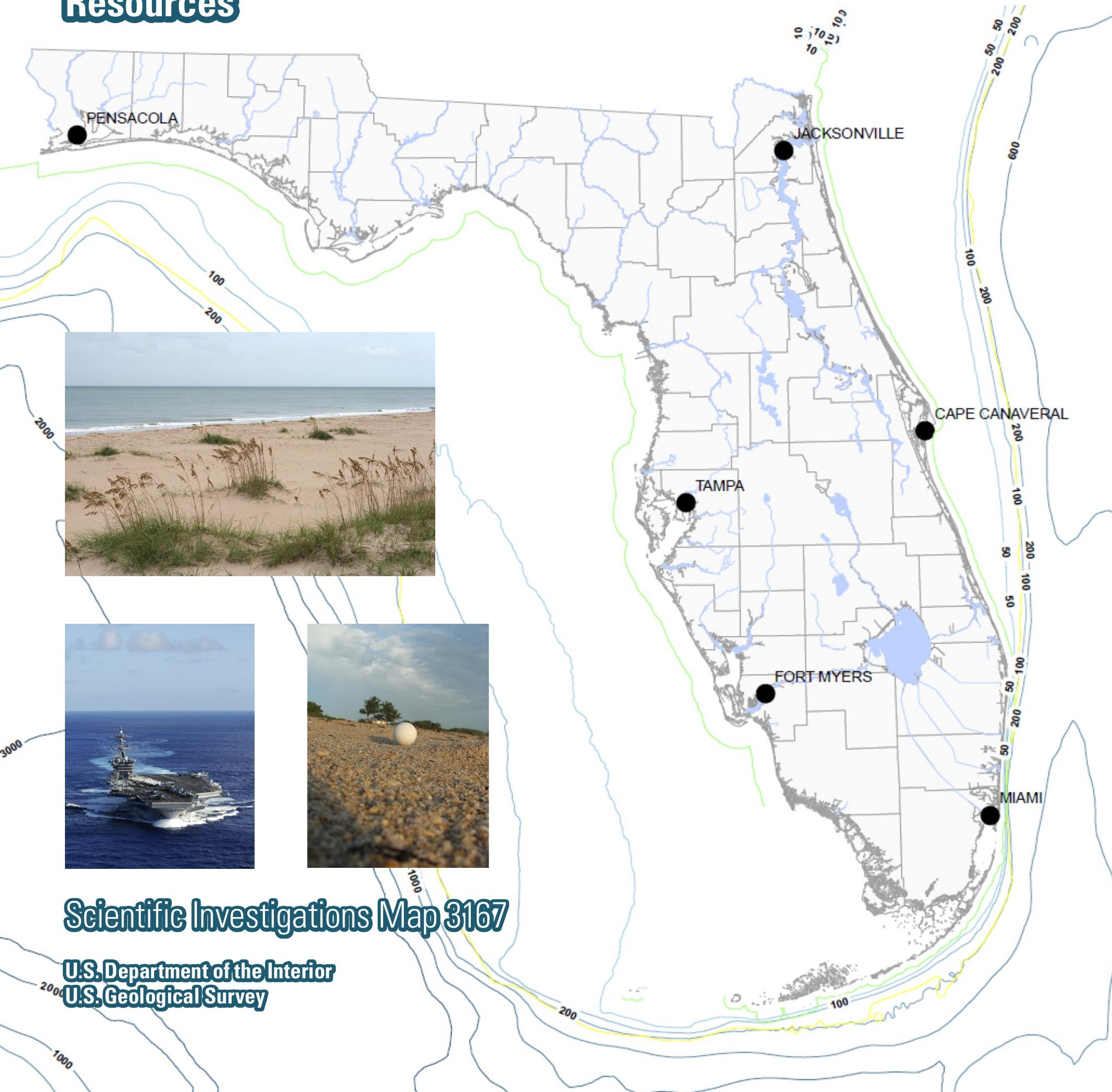




\section{Geospatial Characteristics of Florida's Coastal and Offshore Environments: Coastal Habitats, Artificial Reefs, Wrecks, Dumping Grounds, Harbor Obstructions and Offshore Sand Resources}

By Amanda W.J. Demopoulos, Ann M. Foster, Michal L. Jones, and Daniel J. Gualtieri

U.S. Geological Survey Terrestrial, Freshwater and Marine Ecosystem Program

Scientific Investigations Map 3167 


\section{U.S. Department of the Interior \\ KEN SALAZAR, Secretary \\ U.S. Geological Survey \\ Marcia K. McNutt, Director}

\section{U.S. Geological Survey, Reston, Virginia: 2011}

For more information on the USGS - the Federal source for science about the Earth, its natural and living resources, natural hazards, and the environment, visit http://www.usgs.gov or call 1-888-ASK-USGS

For an overview of USGS information products, including maps, imagery, and publications, visit $h$ ttp://www.usgs.gov/pubprod

To order this and other USGS information products, visit http://store.usgs.gov

Any use of trade, product, or firm names is for descriptive purposes only and does not imply endorsement by the U.S. Government.

Although this report is in the public domain, permission must be secured from the individual copyright owners to reproduce any copyrighted materials contained within this report.

Suggested citation:

Demopoulos, A.W.J., Foster, A.M., Jones, M.L., and Gualtieri, D.J., 2011, Geospatial characteristics of Florida's coastal and offshore environments: coastal habitats, artificial reefs, wrecks, dumping grounds, harbor obstructions and offshore sand resources: U.S. Geological Survey Scientific Investigations Map 3167, 10 p. 


\title{
Geospatial Characteristics of Florida's Coastal and Offshore Environments: Coastal Habitats, Artificial Reefs, Wrecks, Dumping Grounds, Harbor Obstructions and Offshore Sand Resources
}

\author{
By Amanda W.J. Demopoulos, Ann M. Foster, Michal L. Jones, and Daniel J. Gualtieri
}

\section{Introduction}

The Geospatial Characteristics GeoPDF of Florida's Coastal and Offshore Environments is a comprehensive collection of geospatial data describing the political boundaries and natural resources of Florida. This interactive map provides spatial information on bathymetry, sand resources, coastal habitats, artificial reefs, shipwrecks, dumping grounds, and harbor obstructions.

The map should be useful to coastal resource managers and others interested in marine habitats and submerged obstructions of Florida's coastal region. In particular, as oil and gas explorations continue to expand, the map may be used to explore information regarding sensitive areas and resources in the State of Florida.

Users of this geospatial database will have access to synthesized information in a variety of scientific disciplines concerning Florida's coastal zone. This powerful tool provides a one-stop assembly of data that can be tailored to fit the needs of many natural resource managers.

The map was originally developed to assist the Bureau of Ocean Energy Management, Regulation, and Enforcement (BOEMRE) and coastal resources managers with planning beach restoration projects. The BOEMRE uses a systematic approach in planning the development of submerged lands of the Continental Shelf seaward of Florida's territorial waters. Such development could affect the environment. BOEMRE is required to ascertain the existing physical, biological, and socioeconomic conditions of the submerged lands and estimate the impact of developing these lands.

Data sources included the National Oceanic and Atmospheric Administration, BOEMRE, Florida Department of Environmental Protection, Florida Geographic Data Library, Florida Fish and Wildlife Conservation Commission, Florida Natural Areas Inventory, and the State of Florida, Bureau of Archeological Research. Federal Geographic Data Committee (FGDC) compliant metadata are provided as attached $\mathrm{xml}$ files for all geographic information system (GIS) layers.

\section{Acknowledgments}

The U.S. Geological Survey Terrestrial, Freshwater, and Marine Ecosystem Program provided funding for this publication. Metadata included within the GeoPDF credit the various data sources used to create the interactive map. 


\section{Readme First: GeoPDF Navigation Information}

In order to ensure full GeoPDF functionality, please download the toolbar found at www.terragotech.com/products/terragotoolbar. The project description is found on page 1. In order to navigate to the map layers please follow the directions below. The map legends are found on pages 6 and 7.

Scroll down to the map of Florida located on page 5, then click on the stacked diamonds symbol located on the left hand side of the screen (see red circle below).

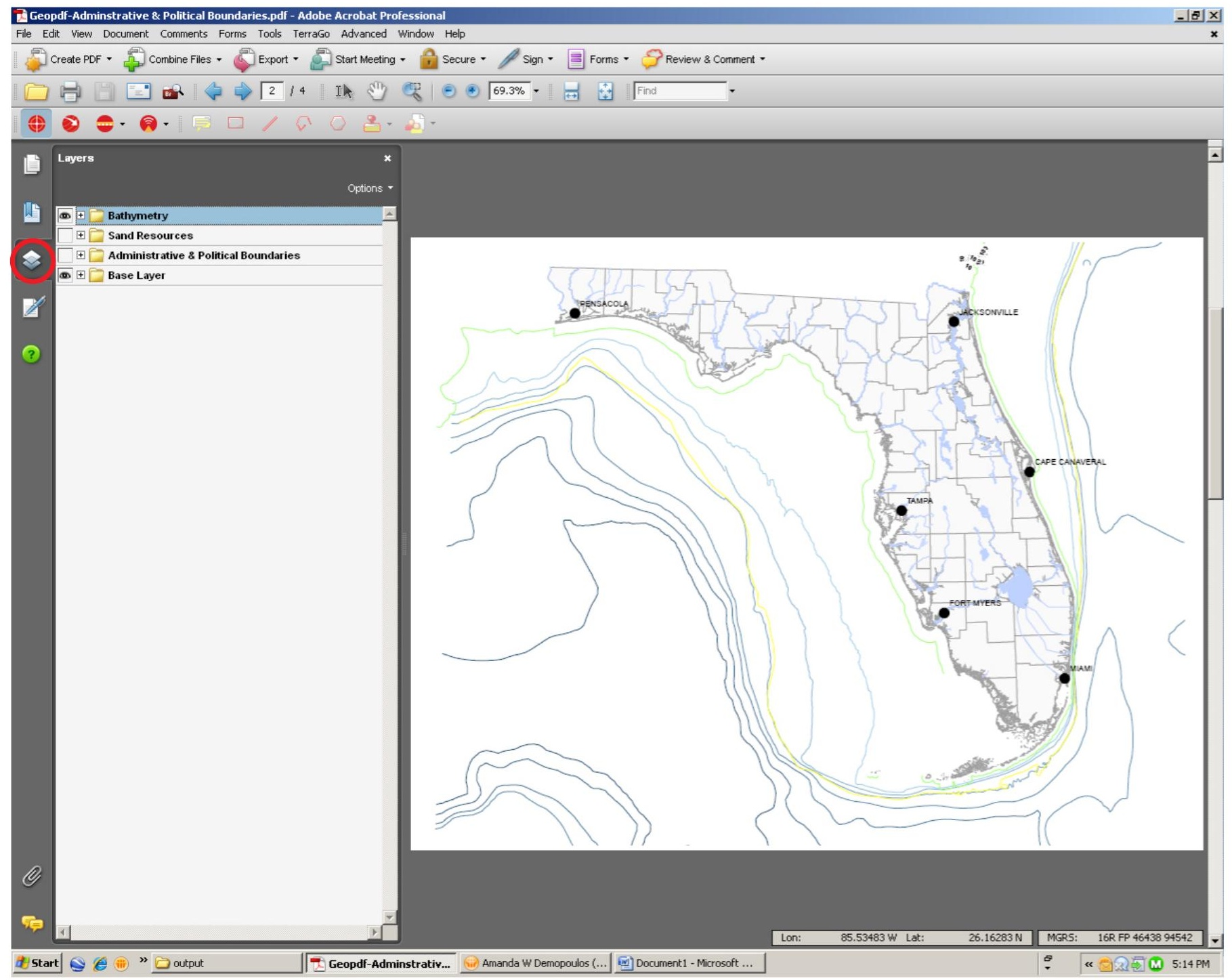


To expand the layers, click on the plus (+) sign (see red circle below).

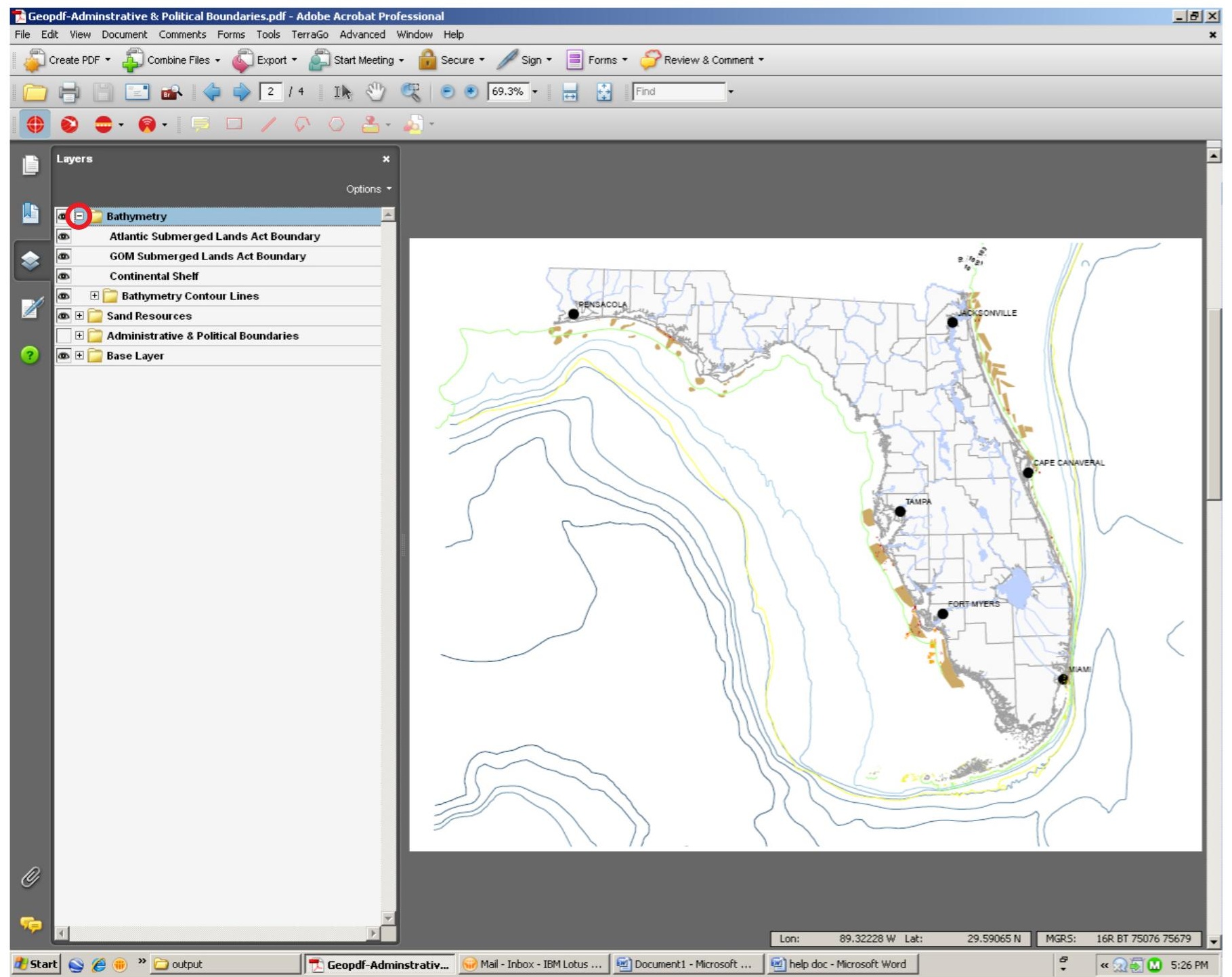


In order to select layers or make them visible, click on the square located next to each layer. An eye will appear when the layer is selected, as shown below (see red circle below).

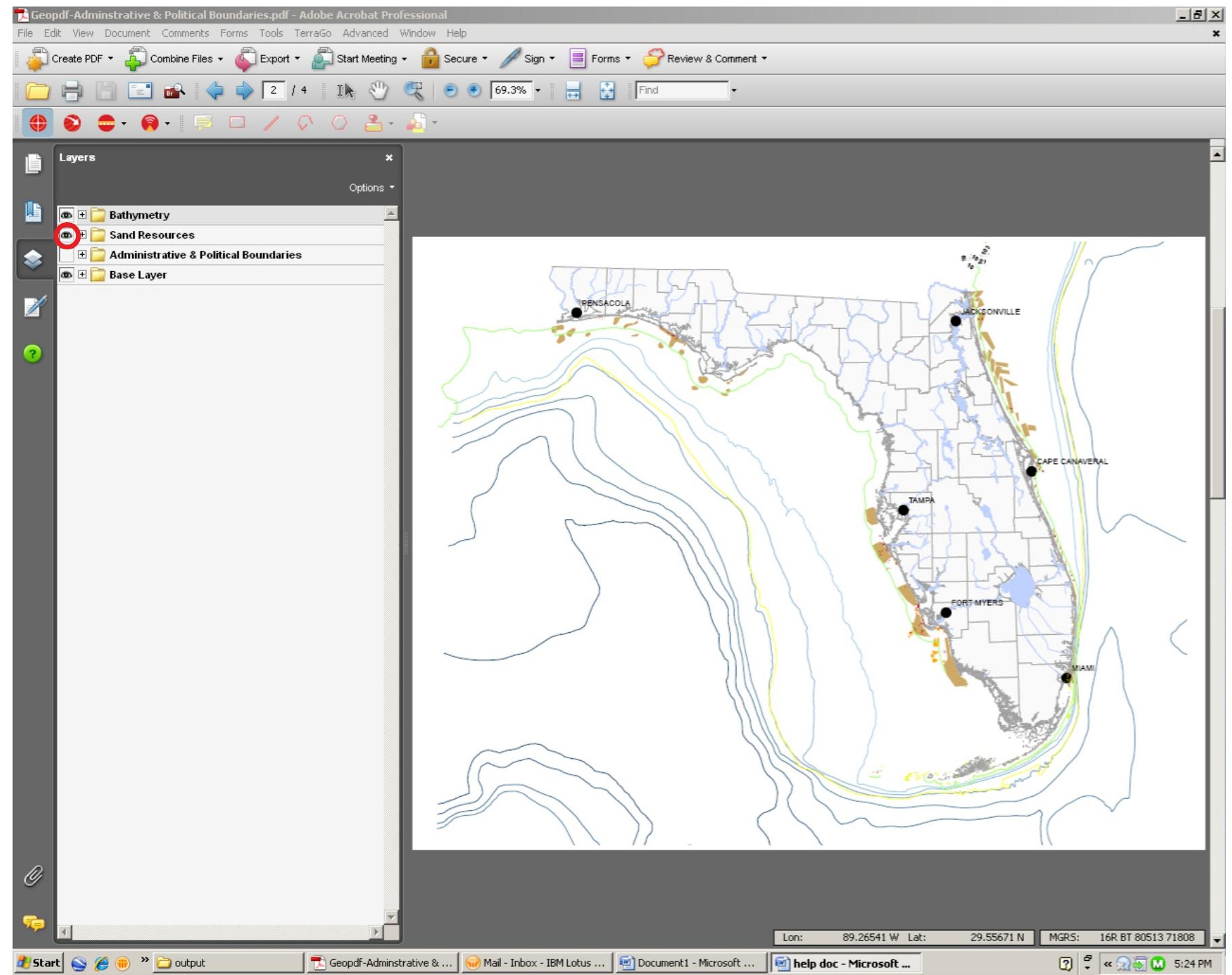




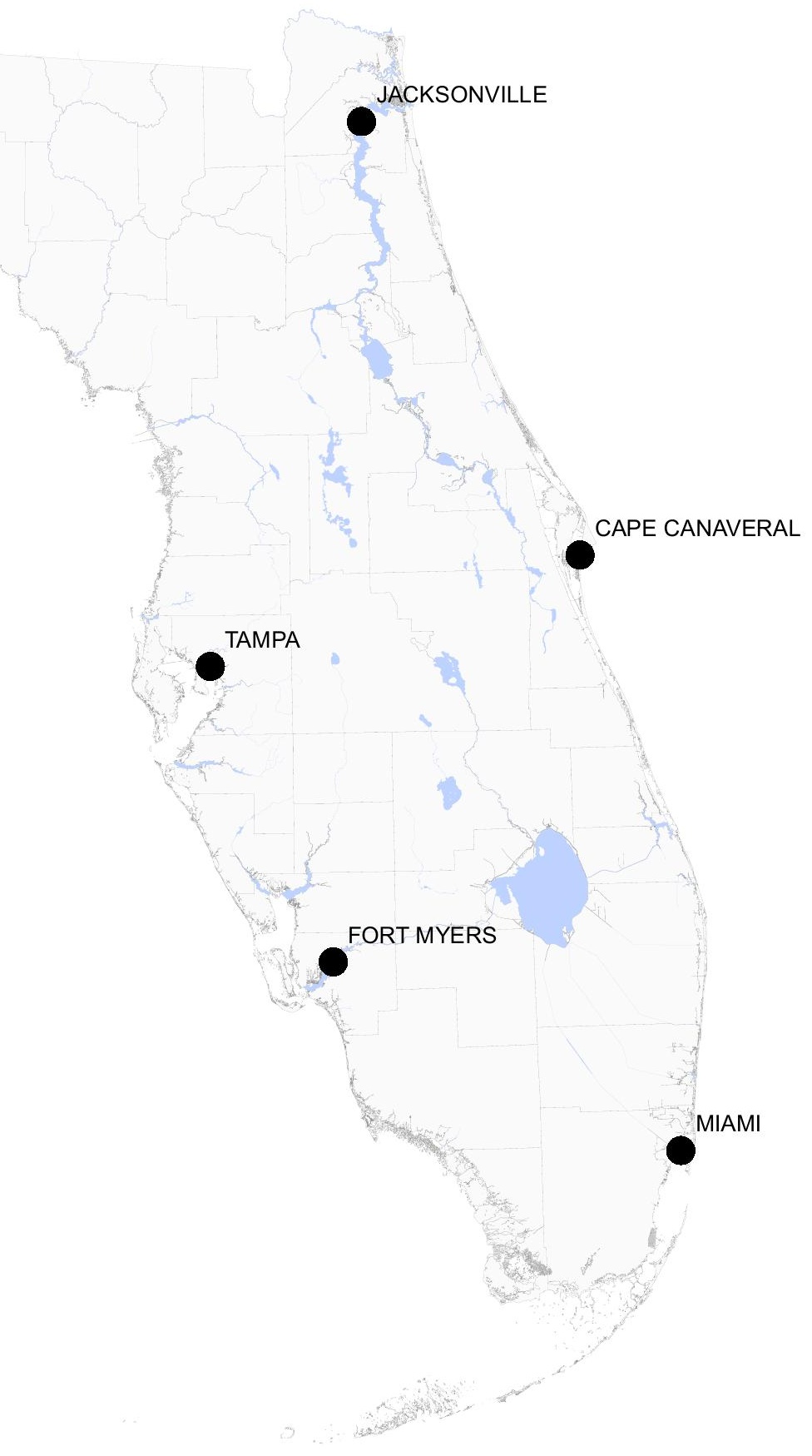




\section{Base, Bathymetry \& Sand Resources}

Florida Counties

$$
\text { Major Rivers }
$$

Major Waterbodies

- Major Cities

Bathymetry Depth in Meters

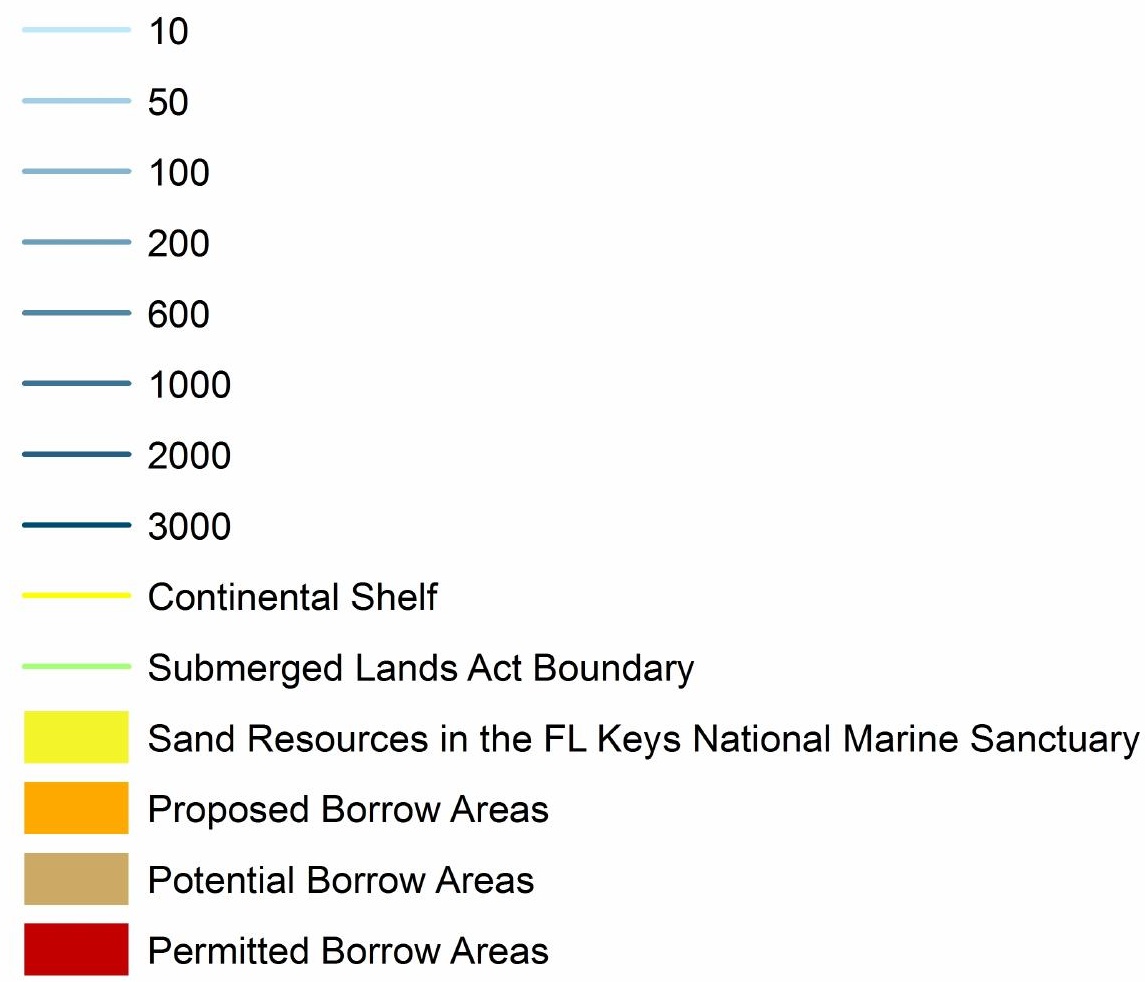




\section{Coastal}

$\begin{aligned} & \text { Seagrass } \\ & \times \quad \text { Artificial Reefs - } 2004 \\ & \circ \quad \text { Artificial Reefs - } 2007 \\ & \quad \text { Reef Locations \& Names } \\ &|||||||| \mid \text { Tidal Flats }\end{aligned}$

× General Dumping Grounds - Points

MV General Dumping Grounds - Polygons

Approach Harbor Dumping Grounds

D Coastal Dumping Grounds

1 Dredged Material Disposal Sites - EPA

Dredged Material Disposal Sites - NOAA

South Florida Benthic Habitats

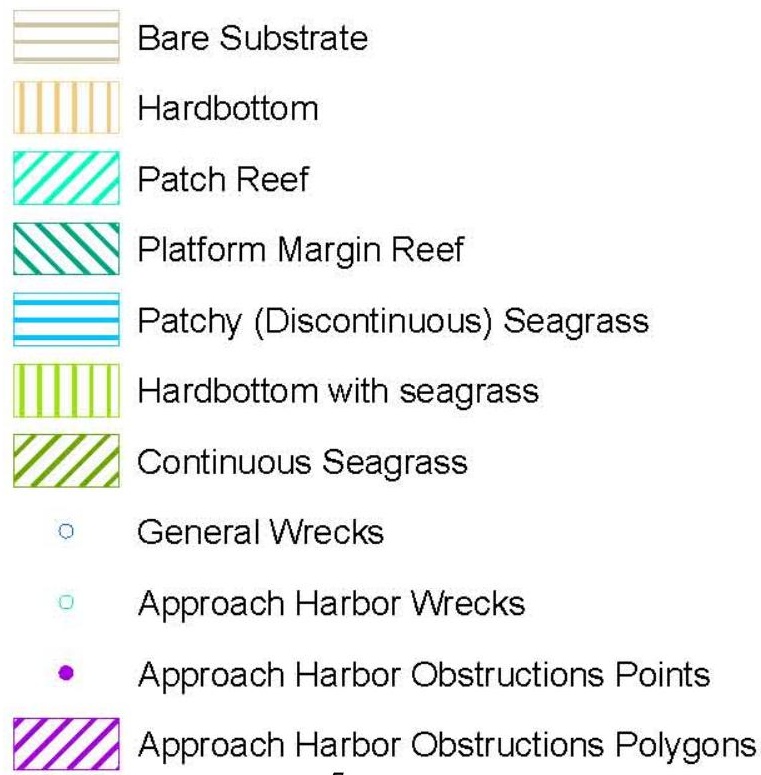

